\title{
Tree regeneration in a New Zealand rain forest influenced by disturbance and drainage interactions
}

\author{
Urlich, Stephen C..$^{*}$; Stewart, Glenn H.; Duncan, Richard P. \& Almond, Peter C. ${ }^{2}$ \\ ${ }^{1}$ Bio-protection and Ecology Division, PO Box 84, Lincoln University, Canterbury, New Zealand; \\ ${ }^{2}$ Agriculture and Life Sciences Division, PO Box 84, Lincoln University, Canterbury, New Zealand; \\ *Corresponding author; Present address: Land Information New Zealand, Private Bag 4721, Christchurch, New Zealand; \\ Fax+64 33659715; E-mail surlich@linz.govt.nz
}

\begin{abstract}
Question: Does canopy tree regeneration response to different large disturbances vary with soil drainage?

Location: Old-growth conifer (Dacrydium and Dacrycarpus), angiosperm (Nothofagus and Weinmannia) rain forest, Mount Harata, South Island, New Zealand.

Methods: Trees were aged (1056 cores) to reconstruct stand history in 20 (0.12-0.2 ha) plots with different underlying drainage. Spatial analyses of an additional 805 tree ages collected from two (0.3-0.7 ha) plots were conducted to detect patchiness for five canopy tree species. Microsite preferences for trees and saplings were determined.

Results: There were clear differences in species regeneration patterns on soils with different drainage. Conifer recruitment occurred infrequently in even-aged patches $\left(>1000 \mathrm{~m}^{2}\right)$ and only on poorly drained soils. Periodic Nothofagus fusca and $N$. menziesii recruitment occurred more frequently in different sized canopy openings on all soils. Weinmannia recruitment was more continuous on all soils reflecting their greater relative shade-tolerance. Distinct periods of recruitment that occurred in the last 400 years matched known large disturbances in the region. These events affected species differently as soil drainage varied. Following earthquakes, both conifers and $N$. menziesii regenerated on poorly drained soils, while Nothofagus species and Weinmannia regenerated on well-drained soils. However, Dacrydium failed to regenerate after patchy storm damage in the wetter forest interior; instead faster-growing $N$. fusca captured elevated microsites caused by uprooting.

Conclusions: Underlying drainage influenced species composition, while variation in the impacts of large disturbance regulated relative species abundances on different soils.
\end{abstract}

Keywords: Conifer; Disturbance history; Earthquake; Environmental gradient; Nothofagus; Regeneration strategy; Soil drainage; Species coexistence; Storm damage.

\section{Introduction}

Two factors often drive variation in the structure and composition of temperate forests. First, underlying environmental variation influences broad patterns of composition and species richness in canopy trees (Whittaker 1956). For example, in southern temperate forests, angiosperms dominate well-drained soils, while conifers are frequently restricted to poorly drained soils (Wardle 1984; Bond 1989; Stewart et al. 1993; Pollmann \& Veblen 2004). Second, disturbances create opportunities for tree regeneration and the nature of openings formed by different types of disturbance may favour regeneration of different species. For example, large infrequent disturbances enable the episodic recruitment of long-lived shade-intolerant species (Oliver \& Stephens 1977; Foster 1988a; Wells et al. 2001), whereas more frequent small-scale canopy openings favour shadetolerant species (Spies \& Franklin 1989; Stewart et al. 1991; Duncan 1993).

Less well understood is how underlying environmental variation interacts with disturbance processes to influence tree regeneration (Crawley 1997). For example, disturbances could create openings of similar size along an environmental gradient, but changes in environmental conditions may favour a different suite of species in different parts of the gradient (e.g. Duncan 1991). Alternatively, as a result of changes in environmental conditions, disturbances of different size or type may be characteristic of different parts of a gradient, again favouring the regeneration of different sets of species (Miller 1982; Foster 1988a; Veblen et al. 1992). In reality, both processes may operate (Duncan 1993) and greater insight into the factors governing species' distribution along environmental gradients may result from considering interactions between disturbance processes and environmental conditions.

Our aim in this study is to investigate how tree regeneration varies in response to disturbance along an underlying drainage gradient. To answer this question, 
we selected a terrace landform in Westland, New Zealand, which has a strong drainage gradient that has been shown to influence tree species composition (Stewart et al. 1993). In addition, we know that large disturbances have been important in structuring forests of this region, and that regeneration has occurred episodically following these events throughout much of Westland (Moorhouse 1939; Duncan 1993; Wells et al. 1998). For example, periodic ruptures of the $500 \mathrm{~km}$-long Alpine Fault over the last 550 years, in AD 1717 (278 a ago), $1630+25$ (365 $\pm 25 \mathrm{a}$ ago $)$, and $1450 \pm 25(545 \pm 25$ a ago $)$, caused regional-wide impacts on forests, resulting in synchronous establishment of shade-intolerant conifers in particular (Wells et al. 1999). Violent storms also cause widespread tree mortality, such as the 1898 storm which extensively damaged Nothofagus stands throughout north Westland (Foster 1931; Stewart et al. 1991). We aim to reconstruct the history of forest regeneration in response to major disturbances across the terrace by aging over 1800 conifer and angiosperm trees. We will use this reconstruction to examine how variation in drainage (across the terrace) and disturbance (through time) interact to determine forest structure and composition.

\section{Methods}

\section{Study area}

Mt. Harata $\left(42^{\circ} 22^{\prime} \mathrm{S}, 171^{\circ} 51^{\prime} \mathrm{E}\right)$ is a granitic dome located in the upper Grey Valley, South Island, New Zealand. It is about $15 \mathrm{~km} \mathrm{~W}$ of the Alpine Fault. Annual rainfall is ca. $2500 \mathrm{~mm}$. We focused on a $1-\mathrm{km}^{2}$ glacial outwash terrace above the Grey River. The terrace is concave with very poorly drained organic soils in the terrace centre, organic soils and poorly drained mineral soils between the centre and margins, and better drained mineral soils around the terrace edges and incised stream sides (Stewart et al. 1993; Urlich 2000). The most abundant conifers on the terrace are the podocarps Dacrydium cupressinum and Dacrycarpus dacrydioides; the most common angiosperms on a range of soils are Nothofagus fusca, N. menziesii and Weinmannia racemosa (Stewart et al. 1993).

\section{Forest age structures}

To identify whether there were distinct periods of recruitment coinciding with dated large disturbances, 1056 trees were aged across the terrace in 20 plots. We relocated forest inventory plots established by Stewart et al. (1993), which were at 100-m intervals along six $\mathrm{N}-\mathrm{S}$ oriented transects spaced $150 \mathrm{~m}$ apart. Plots were qualitatively assessed as either being 'poorly' or 'well' drained: the boundaries between well-drained and poorly drained soils were generally abrupt and able to be delineated in the field. We randomly selected ten plots in both well-drained and poorly drained soils before field sampling. In each plot, we relocated the original central point. At this point, the nearest 15 Dacrydium, Dacrycarpus, $N$. fusca, N. menziesii and $W$. racemosa trees $(\geq$ $5 \mathrm{~cm} \mathrm{DBH}$ ) were cored up to a maximum radius of $20 \mathrm{~m}$ $\left(1256 \mathrm{~m}^{2}\right)$ in any direction in well-drained soils, and 25 $\mathrm{m}\left(1963 \mathrm{~m}^{2}\right)$ in poorly drained soils (Urlich 2000). This gave a maximum of 75 trees per plot (i.e. up to 15 for each species). Data were collected from 1996-1999.

We measured the diameter of all trees $\geq 5 \mathrm{~cm} \mathrm{DBH}$. For multi-stemmed trees we measured the largest stem only, as we wanted to date tree establishment. Every tree was increment cored at $1 \mathrm{~m}$ above ground level. Cores were extracted from the longest radius of the trunk, as this has been determined to provide the most accurate age (Norton et al. 1987; Duncan 1993). After drying and sanding, each individual ring was counted under a binocular microscope. Each ring was assumed to be annual, following other studies that have either demonstrated annual ring production or assumed annual ring growth (Franklin 1969; Norton 1983; Duncan 1993), although missing and false rings have been recorded for several of these species (Norton 1983; Norton et al. 1987). Ages were grouped into 50-a age classes for all trees $<500$ a. Ages were grouped into 100-a classes thereafter, due to the potential for cumulative error. Core age estimates are underestimates of the true age, as no correction was made for time taken for trees to grow to coring height. We standardised core ages to 1995 as the common sampling date, as cores were collected over a three-year period.

For cores that missed the pith but had visible arcs < $50 \mathrm{~mm}$ from the pith, we used a geometric model for calculating the missing portion (Duncan 1989). We used age/diameter relationships to estimate ages for $7 \%$ cores which either had arcs $>50 \mathrm{~mm}$ from the pith, or were $<70 \%$ of the length to the estimated geometric centre. All age/diameter regression equations were significant at the $\alpha=0.01$ level (Urlich 2000). We estimated ages for rotten cores short of the chronological centre (5\% cores) by assuming the distance to the geometric centre represented the distance to the chronological centre (Norton et al. 1987).

\section{Terrace disturbance history}

To determine if there were distinctive recruitment pulses for different species within the 20 individual plots, we devised the following conservative criteria to identify relatively even-aged groups of trees: 1 . In each plot $\geq 50 \%$ trees had to be aged all within 50 years if the oldest tree was $\leq 250$ a old, and $\geq 50 \%$ trees aged within 
100 a if the oldest tree was $>250$ a old. 2 . There had to be a $>50$-a gap (one age-class) between the oldest tree in the even-aged group, and the next oldest tree. This was to distinguish pulsed from more continuous recruitment for the shorter lived angiosperms in particular.

\section{Microsite establishment patterns}

We identified establishment microsites for all trees as either ground (forest floor, pit) or elevated (mound, stump, $\log$, or tree fern trunk). If a microsite establishment site was not clearly identifiable we recorded it as ground.

\section{Within-stand dynamics}

We analysed the spatial distribution of an additional 805 tree ages in two large rectangular plots to reconstruct stand development. We established one plot in each of two areas with contrasting soil drainage and forest types identified by Stewart et al. (1993). Plot locations were randomly selected, and were $300 \mathrm{~m}$ apart. Plot B $(100 \mathrm{~m} \times 70 \mathrm{~m})$ was sited halfway between the terrace centre and margins in peats (Sapric Haplohemists, $50-120 \mathrm{~cm}$ in depth) and poorly drained more mineral soils (Terric Haplohemists, $50-80 \mathrm{~cm}$ in depth). Plot C $(60 \mathrm{~m} \times 50 \mathrm{~m})$ was placed in well-drained soils (Spodic Drystrudepts, $30-60 \mathrm{~cm}$ in depth) near the terrace edge (Urlich 2000). Plot boundaries were oriented to ensure that they did not traverse any obvious soil drainage or forest structural boundaries. Trees were cored and aged in these two large plots in the same way as the 20 terrace plots, except every second tree between $5-10 \mathrm{~cm} \mathrm{DBH}$ was cored in plot B. Ages were estimated from agediameter regression equations for trees not aged (see forest age structures). Cores from plot $\mathrm{C}$ were crossdated for a separate study (Vittoz et al. 2001), and were in accord with uncross-dated ages by their placement in the same age-classes (Urlich 2000).

\section{Spatial patterns}

In detecting even-aged patches of trees in plots B and $\mathrm{C}$, we analysed whether or not tree ages were spatially autocorrelated using Moran's $I$ coefficient (Moran 1950). This was done based on their $x, y$ coordinates in $5 \mathrm{~m} \times 5 \mathrm{~m}$ quadrats following the methods outlined in Duncan \& Stewart (1991). We constructed spatial correlograms to examine the level of autocorrelation with distance (Legendre \& Fortin 1989). If the shape of the correlogram showed evidence for patchiness, we used agglomerative hierarchical clustering (UPGMA in the package PATN; Belbin 1989) to identify groups of even-aged trees based on their age and spatial location.
Table 1. Microsite establishment patterns for trees in 20 plots in two different underlying drainage classes at Mt. Harata, Westland, New Zealand. Ground sites are forest floor and pits; elevated sites include logs, mounds, stumps, and tree fern trunks.

\begin{tabular}{lrrrrrr}
\hline \multirow{2}{*}{ Species } & \multicolumn{3}{c}{ Poorly drained plots } & \multicolumn{3}{c}{ Well-drained plots } \\
& Elevated & Ground & Total & Elevated & Ground & Total \\
\hline Dacrydium & 2 & 125 & 127 & 5 & 8 & 13 \\
Dacrycarpus & 2 & 95 & 97 & 0 & 1 & 1 \\
N. fusca & 108 & 13 & 121 & 54 & 91 & 145 \\
N. menziesii & 136 & 11 & 147 & 54 & 86 & 140 \\
W. racemosa & 105 & 24 & 129 & 73 & 77 & 150 \\
Totals & $\mathbf{3 5 3}$ & $\mathbf{2 6 8}$ & $\mathbf{6 2 1}$ & $\mathbf{1 8 6}$ & $\mathbf{2 6 3}$ & $\mathbf{4 4 9}$ \\
\hline
\end{tabular}

\section{Results}

\section{Compositional variation across the gradient}

There were differences in species composition on the differently drained soils along the terrace (Table 1). Conifers were dominant in poorly drained soils, often as large emergents over a Nothofagus dominated canopy and Weinmannia racemosa sub-canopy. However, conifers were scarce or not present at all in well-drained soils, with Dacrydium present in half the plots and Dacrycarpus (1 tree) in one plot only. Forest structure on well-drained soils was, therefore, markedly different, with $N$. fusca dominating the canopy with associated $N$. menziesii over a $W$. racemosa sub-canopy.

Species microsite preferences changed with drainage class (Table 1). On poorly drained soils conifers occurred on the ground, whereas angiosperms were mostly on elevated sites. On well-drained soils

Table 2. Mean annual stem growth rates $\left(\mathrm{cm} \cdot \mathrm{a}^{-1}\right)$ with standard deviation $( \pm \mathrm{SD})$ and range $\left(\mathrm{cm} \cdot \mathrm{a}^{-1}\right)$ over the first $50 \mathrm{yrs}$ of growth after reaching coring height in differently drained soils at Mt. Harata, Westland, New Zealand. Kruskal-Wallis (K-W) tests were used to test for differences between means, with different letters representing a significant difference at the $P<$ 0.01 level. Also shown is the estimated time taken for trees to grow to $1 \mathrm{~cm} \mathrm{DBH} \mathrm{(as} \mathrm{a} \mathrm{surrogate} \mathrm{for} \mathrm{time} \mathrm{to} \mathrm{grow} \mathrm{to} \mathrm{tree}$ coring height of $1 \mathrm{~m}$ ), based on their mean annual growth rates in different soils.

\begin{tabular}{lccccc}
\hline Species & $n$ & $\begin{array}{c}\text { Growth } \\
\text { rate } \pm \text { SD }\end{array}$ & Range & $\begin{array}{r}\text { K-W } \\
\text { test }\end{array}$ & $\begin{array}{c}\text { DBH } \\
\text { growth }\end{array}$ \\
\hline Poorly drained soils & & & & & \\
Nothofagus fusca & 66 & $0.23 \pm 0.15$ & $0.05-0.75$ & $\mathrm{~A}$ & 4 \\
Nothofagus menziesii & 86 & $0.11 \pm 0.07$ & $0.03-0.44$ & $\mathrm{~B}$ & 9 \\
Dacrycarpus & 57 & $0.11 \pm 0.06$ & $0.04-0.29$ & $\mathrm{~B}$ & 9 \\
Dacrydium & 55 & $0.10 \pm 0.05$ & $0.04-0.28$ & $\mathrm{~B}$ & 10 \\
Weinmannia racemosa & 52 & $0.10 \pm 0.03$ & $0.04-0.21$ & $\mathrm{~B}$ & 10 \\
Well-drained soils & & & & & \\
Nothofagus fusca & 39 & $0.30 \pm 0.14$ & $0.05-0.62$ & $\mathrm{~A}$ & 3 \\
Nothofagus menziesii & 59 & $0.19 \pm 0.10$ & $0.04-0.42$ & $\mathrm{~B}$ & 5 \\
Weinmannia racemosa & 61 & $0.12 \pm 0.05$ & $0.05-0.28$ & $\mathrm{C}$ & 8 \\
\hline
\end{tabular}


angiosperms switched their main preference to ground microsites. $N$. fusca grew consistently faster than other species on all soils (Table 2). Based on the time taken to reach $1 \mathrm{~cm} \mathrm{DBH} \mathrm{(as} \mathrm{a} \mathrm{surrogate} \mathrm{for} 1 \mathrm{~m}$ coring height), $N$. fusca averaged 3-4 years in differently drained plots (Table 2), reflecting a rapid response to disturbance.

\section{Disturbance history and forest age structures}

We pooled the 1056 tree ages by species for welland poorly drained soils separately and constructed ageclass frequency histograms (Fig. 1). All species had modal peaks in their age-class frequency distributions on at least one of the two drainage classes that coincided with one or more of the known disturbance dates. Dacrycarpus, N. fusca and N. menziesii had corresponding peaks on different soils indicating episodic synchronous recruitment, which is consistent with a response to large disturbances affecting the terrace. However, Dacrydium did not have peaks in the same age-class as the other species, possibly reflecting different responses to these disturbances.

In poorly drained soils, Dacrydium had multi-modal peaks corresponding to at least two Alpine Fault earthquakes 250-300 years and 500-600 a ago, but there was little evidence of a response to storms ca. 100 a ago (Fig. 1a). In contrast, the other conifer Dacrycarpus had age-class frequency peaks coinciding with disturbances ca. 100 a ago and the earthquake ca. 365 years ago (Fig. 1b). Along with Dacrycarpus, N. fusca also had $>30 \%$ stems in the 50-100-a age class (Fig. 1c). N. menziesii and $W$. racemosa exhibited more continuous recruitment over the last 300 years, particularly 100-200 a ago when recruitment of other species was relatively low (Fig. 1d, e). In the well-drained soils, both Nothofagus species and $W$. racemosa had peaks comprising $\geq 40 \%$ stems in the 50-100-a age-class corresponding to the storms (Fig. 1g-i).

To test whether similar patterns occurred at the individual plot level, we analysed each plot for evenaged groups of trees of each species (Fig. 2). All plots had at least one and as many as four even-aged groups, and the majority of these groups were associated with known disturbance events.

Generally synchronous regeneration within plots was rare and even more so on poorly drained plots. In $40 \%$ of the well-drained plots, different species had similarlyaged groups such as $N$. menziesii and $W$. racemosa in plot A6; N. fusca and N. menziesii in plots D1, C10 and F11, reflecting synchronous regeneration. In the poorly drained plots, different species had different-aged groups indicative of more patchy recruitment on these plots, such as Dacrycarpus (290-386 a), Dacrydium (213-280 a), $N$. fusca (77-120 a) in plot D9; Dacrydium (552-645 a), Dacrycarpus (271-345 a), N. menziesii (213-303 a) and $N$. fusca (62-106 a) in plot C9.

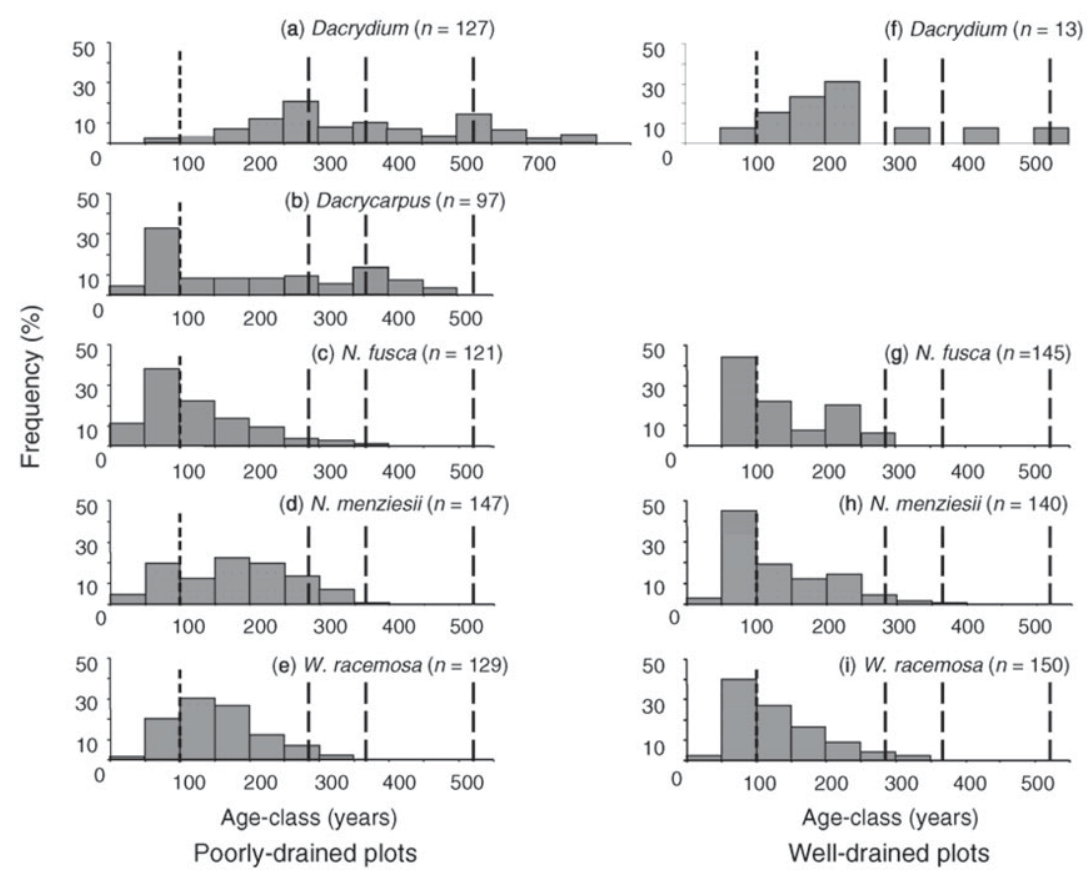

Fig. 1. Age-class frequency distributions for five canopy tree species $(n=1056)$ in ten well-drained plots and ten poorly drained plots at Mt. Harata, Westland, New Zealand. Short dashed lines represent the 1898 storm that caused extensive blowdown in north Westland forests. Long dashed lines represent reconstructed dates of past Alpine Fault earthquakes. There were not enough Dacrycarpus trees (one only) to graph in well-drained plots. 
Tree age (years)

Fig. 2. Age ranges of identified even-aged groups of trees for five canopy tree species from 10 poorly drained and 10 well-drained plots, Mt Harata, north Westland, New Zealand. Also shown are the date ranges of reconstructed Alpine Fault earthquakes, and known storms in the north Westland region.

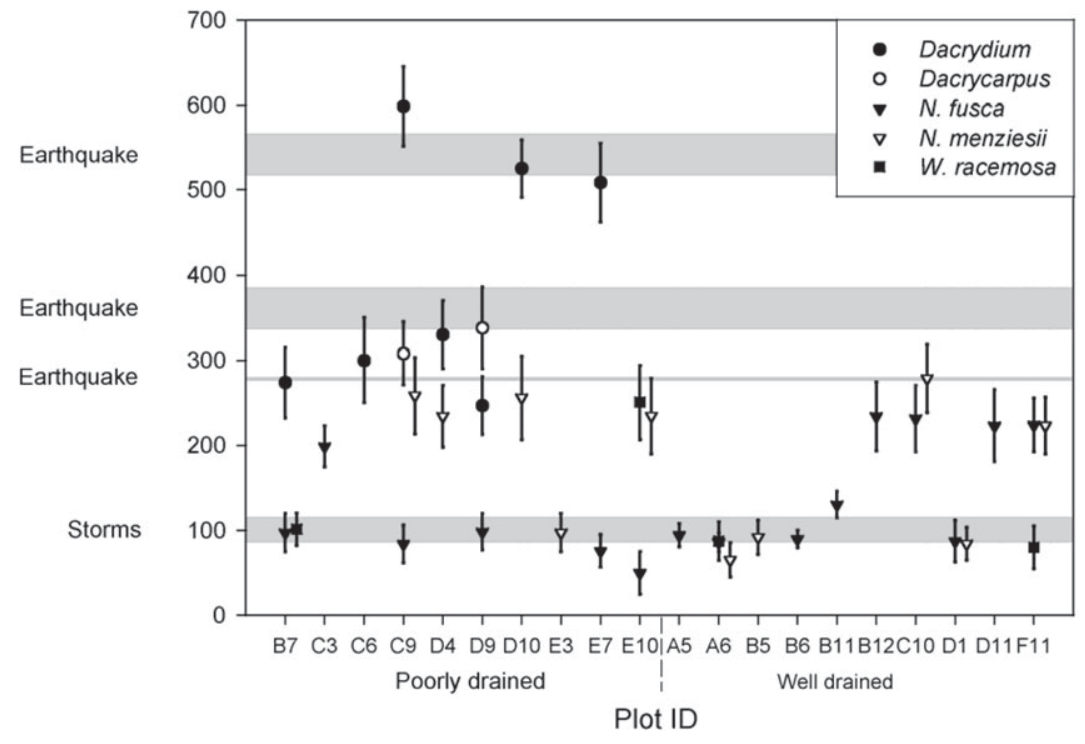

The fact that multiple even-aged groups occurred within $50 \%$ of the poorly drained plots indicates that canopy disturbances promoting regeneration were smaller than the ca. $1500 \mathrm{~m}^{2}$ size of the plots. If multiple disturbances affected areas much larger than the plots the corresponding recruitment pulses would be evident in the pooled age-class data, but individual plots would contain only one or perhaps two different even-aged groups. There were only two different even-aged groups in the well-drained plots, which may reflect a tendency for larger canopy disturbances on these soils. This is explored further below in the spatial analysis of the large Plot $\mathrm{C}$ on well-drained soils.

There were even-aged groups that did not match known large disturbances, such as Dacrydium (552-645 a in plot C9), and N. fusca (115-146 a in B11 and 175223 a in C3). The criteria we used excluded some probable even-aged groups for Dacrydium (225-328 a in plot C3, 436-538 a and 754-889 a in E3), and for Dacrycarpus (47-126 a in plot C3, 45-129 a in E3, and 42-115 a in E10). Protracted Dacrycarpus recruitment may partly explain why the pulse evident in the 50-100a class (Fig. 1b) did not clearly show up in individual plots (Fig. 2).

\section{Within-stand dynamics}

\section{Poorly drained plot $B$}

Dacrydium had a discontinuous age-class structure which showed $76 \%$ of surviving trees established between 800-900 a, 600-700 a and 300-400 a ago (Fig. $3 a)$. The population had a significant spatial structure $(P$ $<0.01, n=38$ ), and positive values at short to mid- distances (1-20 m) suggested trees of similar age were autocorrelated. Different aged groups of trees were mapped, and were in different parts of the plot consistent with response to large, infrequent disturbances (Fig. 4a).

Dacrycarpus also had a discontinuous age-class structure (Fig. 3b). The shape of the distribution was similar to the terrace plots (Fig. 1b), both sets of data having a peak in the 50-100-a class. Patchiness in tree ages was detected after spatial analysis $(P<0.01, n=32)$; positive values at short distances $1-6 \mathrm{~m}$, and negative values from 18-21 m, indicated trees were in small groups in different parts of the plot. Three spatially distinct groups of trees were identified and mapped (Fig. 4). The oldest Dacrycarpus group (303-417 a) coincided in age with the youngest Dacrydium group (287-398 a), matching the date range of an earthquake (Fig. 2). Most trees were located close together suggesting synchronous regeneration in response to a large canopy opening (Fig. 4a). The youngest Dacrycarpus group (30-102 a) were mostly clumped in groups of three to six trees (Fig. 4d), in uprooted areas suggesting gap-phase regeneration among older surviving trees.

The $N$. fusca population was dominated by stems < 100 years old, which were distributed around the plot (Fig. 3c). Many concentrated around the middle and lower sections of the plot, with similarly-aged Dacrycarpus and N. menziesii (Fig. 4d).

$N$. menziesii and $W$. racemosa had more stems aged between 100-250 years than other species (Fig. 3d, e). N. menziesii had a significant spatial structure $(P<0.01$, $n=128$ ); positive values at $1-6 \mathrm{~m}$ and $45-51 \mathrm{~m}$, and negative values at $27-30 \mathrm{~m}$ and $54-57 \mathrm{~m}$ indicated small 
groups of similarly-aged trees were spread throughout the plot. This was reflected in the stem maps, where the majority of stems were progressively recruited into the overstorey between 100-250 a ago, mostly in small gaps around the emergent, old Dacrydium (Fig. 4 c). The ageclass structure for $W$. racemosa appeared to show a cohort age structure (Fig. 3e), but this was not supported by spatial analysis. W. racemosa were commonly multistemmed with different-sized stems and frequent epicormic growth. As we cored the largest stem only, we could not determine whether $W$. racemosa recruitment was more continuous or pulsed.

\section{Well-drained plot $C$}

There were no Dacrycarpus and only three Dacrydium trees in this plot; these were aged between 226-439 a. Both Nothofagus species had abrupt peaks in the 50100-a age-class (Fig. 3f, g). These populations had a significant spatial structure ( $N$. fusca: $n=58, P<0.01$; N. menziesii: $n=128, P<0.01)$, and similarly-aged stems were positively autocorrelated from 1-24 m for both species. This was reflected in at least two distinctive groups of different aged trees in different parts of the plot (Fig. 5). N. fusca and N. menziesii (>125 a) were more regularly spaced in approximately one half of the plot, than the younger Nothofagus cohort (Fig. 5 a). The youngest $N$. fusca $<125$-a group were mostly clustered together with similarly-aged N. menziesii in a dense pole stand (Fig. 5b), reflecting a stand-building phase that began ca. 100 a ago covering $>1500 \mathrm{~m}^{2}$. These stems established on mounds, and amongst uprooted boles which had fallen in a NW direction indicating wind throw. In contrast, W. racemosa of similar age to the young Nothofagus cohort were distributed throughout the plot. These stems were near dead-standing and uprooted trees, and among older, living trees.

\section{Discussion}

\section{Evidence for large disturbances}

Species age structures across the terrace showed distinct pulses of coinciding episodic recruitment consistent with responses to large disturbances. The grouped age ranges in individual terrace plots, pooled age-class data from these plots, and in the two large plots, matched known, or reconstructed, dates of large disturbances that affected the north Westland region. We suggest the most recent disturbance is due to storm impacts, while the older events are earthquake related. Evidence for violent storms between 90-120 years ago comes from historical records (Foster 1931; Benn 1990), such as the 1898 storm which caused widespread blow-down in the region (Foster 1931; Moorhouse 1939).

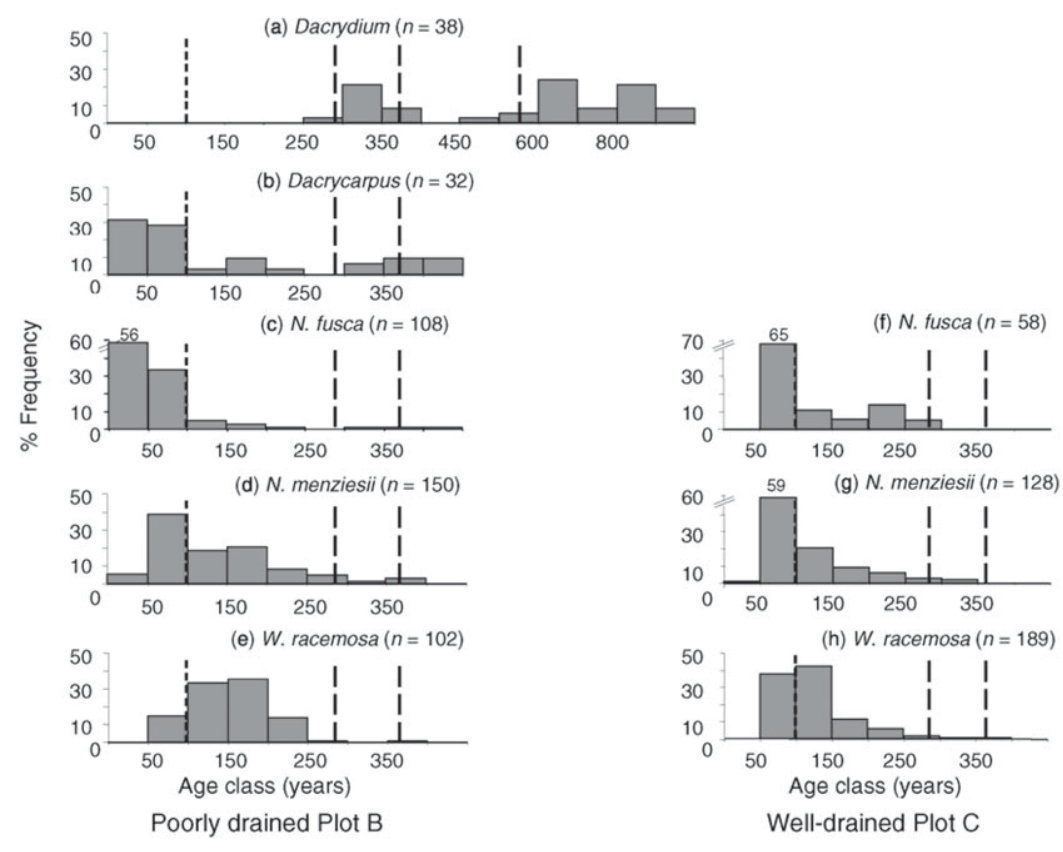

Fig. 3. Age-class frequency distributions for five canopy tree species in two plots (0.3-0.7 ha) in differently drained soils at Mt. Harata, Westland, New Zealand $(n=805)$. (A-E) poorly drained Plot B. (F-H) well-drained Plot C. Short dashed lines represent the 1898 storm that caused extensive blowdown in north Westland forests. Long dashed lines represent dates of reconstructed past Alpine Fault earthquakes. There were not enough Dacrydium and Dacrycarpus trees to graph in Plot C. 
(a) stems $>300 a$

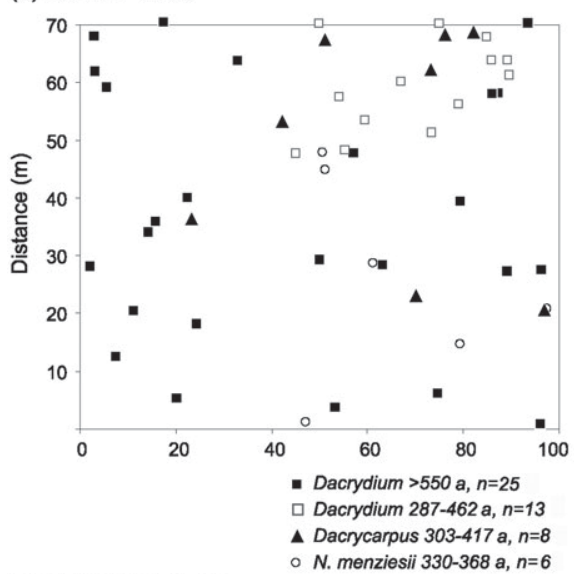

(c) stems 100-200 a

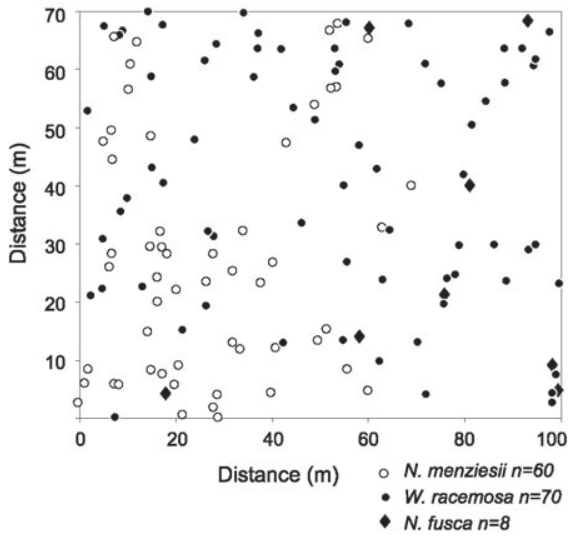

(b) stems 200-300a

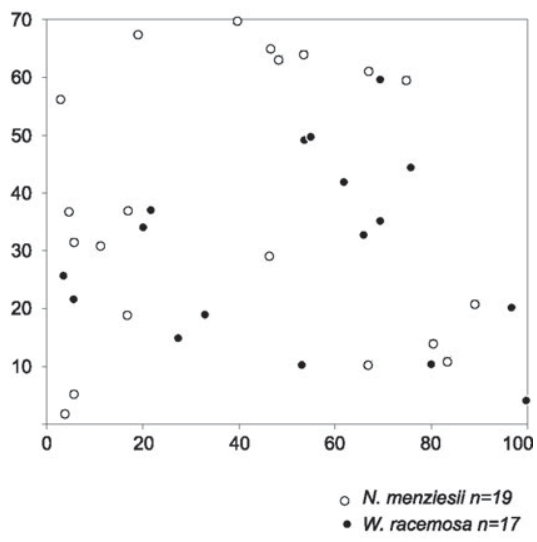

(d) stems $<100$ a

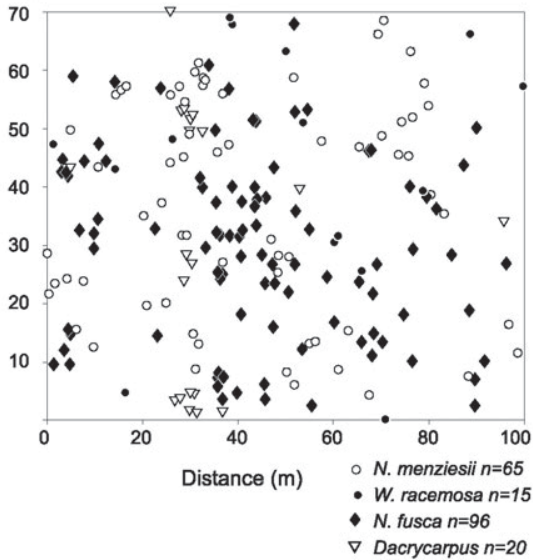

Fig. 4. Stem age maps for five overstorey species in poorly drained soils (plot B), Mt. Harata, Westland, New Zealand. Only species with $>$ five stems in each age band are shown. a. Groups of relatively even-aged trees $>300$ a identified after spatial analysis (including two Dacrydium outliers of 287 and 462 a - the other 11 stems were aged 309-398 a). b. Stems 200-300 a dominated by N. menziesii and W. racemosa, and also (c) 100-200 a in amongst the oldest Dacrydium cohort. The stem map (d) shows the upsurge in recruitment for N. fusca, N. menziesii and Dacrycarpus in the last 100 years.

(a) Nothofagus stems $>125$ a

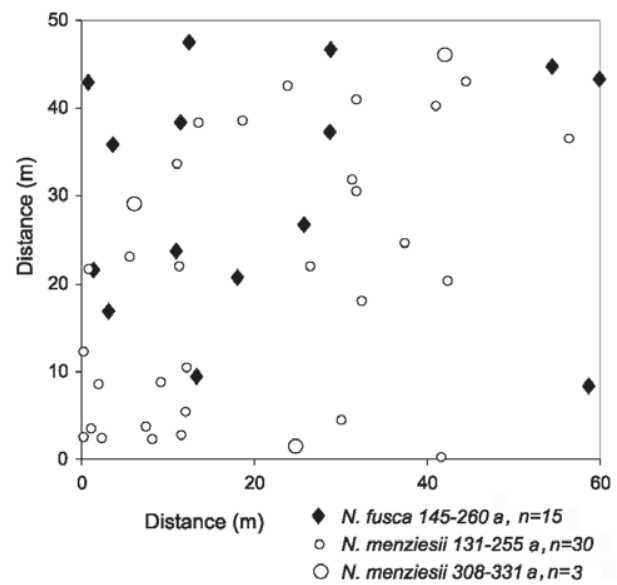

(b) Nothofagus stems $<125$ a

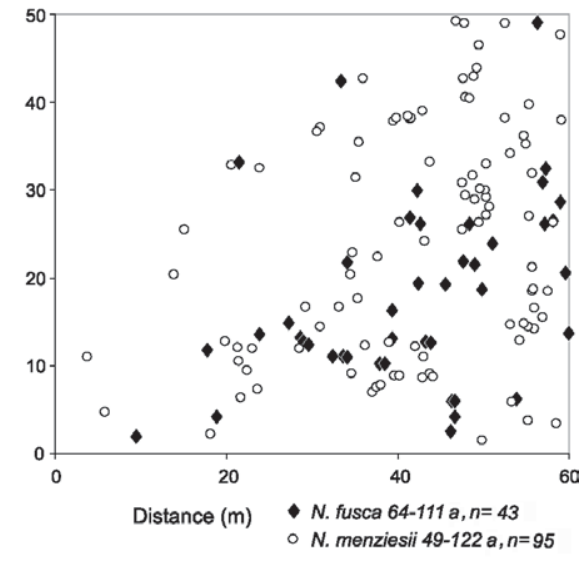

Fig. 5. Stem maps for Nothofagus species in well-drained soils (plot C), showing patches of different age identified after spatial analysis. a. N. fusca and N. menziesii $>125$ a. b $N$. fusca and $N$. menziesii $<125$ a. 
Widespread synchronous establishment of Nothofagus stands, dated from tree cores within a $30 \mathrm{~km}$ radius of our study site, also coincided with these storms, particularly the 1898 event (Smale et al. 1987; Stewart et al. 1991; Cullen et al. 2001). There were three largescale ruptures of the $500 \mathrm{~km}$ Alpine Fault between 278550 a ago, but no movement in the last 150 years (Wells et al. 1999). Here we extend the impacts of these $M_{w} 8+$ events farther into north Westland (cf. Urlich 2000), and provide some evidence from Dacrydium ages of possible older earthquakes ca. $650 \mathrm{a}$ and ca. $900 \mathrm{a}$ ago at the site (Figs. 1 and 2). Increased periods of storminess could be another potential cause of the older recruitment pulses. Grant (1985) suggested there was a period of increased storminess 495-375 a ago which resulted in increased aggradation events; however, we did not find even-aged groups spanning this age range. No evidence of other disturbance types, such as landsliding or flooding, was detected.

There is likely to have been a rapid regeneration response following past large disturbances. The growth rate data indicated that it takes less than five years for $N$. fusca to reach coring height, and about 10 years for other species in poorly drained soils (Table 2). Preexisting seedlings of each species were observed in differently drained plots (unpubl. data), suggesting there is unlikely to be a delay in establishment after disturbance. Therefore, the age-ranges of the identified groups probably represent a reasonably close accord with the dates of past disturbances (Fig. 2). Coarse-scale disturbances, such as earthquakes and storms, can also have prolonged effects on overstorey mortality in New Zealand forests (Vittoz et al. 2001). Long periods of dieback following major disturbance have been documented in Nothofagus forests, as insect outbreaks and drought kill trees weakened by these disturbances (Hosking \& Kershaw 1985; Vittoz et al. 2001). This could potentially explain protracted recruitment (Fig. 2), as the canopy continued to be opened up by ongoing mortality, and/or post-disturbance conditions ameliorated over time.

\section{Species response to disturbances across the drainage gradient}

Two main patterns were evident in how species responded to these events. First, different species responded to the same disturbance on differently drained soils, reflecting the influence of underlying drainage on species distributions. For example, following the earthquake in 1717, Dacrydium and N. menziesii recruitment occurred in more than one plot on poorly drained soils, whereas $N$. menziesii and $N$. fusca responded on welldrained soils (Figs. 1 and 2). Similarly, after the storms ca. 100 a ago, Dacrycarpus, N. fusca and N. menziesii regenerated in poorly drained soils, whereas both Nothofagus species and W. racemosa dominated on welldrained soils. Second, in the same plot, different species responded to disturbances at different times, suggesting there was something about the nature of the impacts that favoured a different suite of species. For example, longlived Dacrydium populations in poorly drained terrace soils were characterised by relatively even-aged groups, which generally coincided with past earthquakes, but there was little evidence of a response to the more recent storms. Spatial analyses of tree age distributions in the two large plots (B and $\mathrm{C}$ ) provided further evidence that each species did not respond in a similar way to disturbances on differently drained soils (Figs. 4 and 5).

The consequent availability of suitable microsites following these disturbances appeared to be a key influence in determining which species were recruited into the overstorey. Angiosperms dominated better drained mounds and logs in poorly drained soils, whereas the conifers were restricted to saturated forest floor soils (Table 1). These microsite patterns appear to be common in mixed conifer, Nothofagus forests in high rainfall areas of the South Island (June 1982; Veblen \& Stewart 1982), and in the North Island (Rogers 1989). As such, there appears to be an element of determinism in species regeneration patterns depending on the interaction of disturbance and drainage factors in temperate Westland rainforests (cf. Duncan 1993). Elsewhere in the world underlying soil conditions and disturbance impacts can be strong drivers of tree species diversity (Romme \& Knight 1981; Harmon et al. 1983; Foster 1988a; Rogers 1989; Veblen et al. 1992; Pollmann \& Veblen 2004).

\section{Differentiating storm and earthquake impacts}

The size of even-aged patches seemed to be larger on the well-drained soils following the storms. Storm damage resulted in extensive mortality and relatively synchronous cohort recruitment $\left(>1000 \mathrm{~m}^{2}\right)$ in well-drained soils near the terrace edge and margins (Figs. 2 and 5). In contrast, more patchy recruitment occurred in the poorly drained forest interior at the same time; for example, Dacrycarpus and Nothofagus recruitment occurred amongst older surviving Dacrydium trees (Fig. 4d). Impact intensities from large winds can vary across land forms depending on exposure to prevailing wind velocity and direction, stand composition and structure, and variability in edaphic conditions (Foster 1988b; Boose et al. 2004). Conifer regeneration patterns in plot B suggest the earthquake opened up large areas of the forest canopy 350-400 a ago. Earthquakes cause extensive forest damage and tree mortality, with severe shaking effects including root shearing, limb breakage, or 
toppling (Kitzberger et al. 1995; Wells et al. 2001). Trees on unstable soils with high water tables, such as organic soils in poorly drained areas, are particularly susceptible to toppling due to liquefaction as they provide weak rooting media (Kitzberger et al. 1995; Almond 1997). Due to the general absence of long-lived conifers on well-drained soils it is difficult to determine how past earthquakes had affected forests on these soils. It may be that well-drained soils are inherently stronger, so that only extreme shearing by storm winds is sufficient to topple large tracts of forest. However, the comparatively shorter life span of Nothofagus and Weinmannia (200-400 a) must also be considered when looking for responses to older events (Stewart et al. 1991). The more recent storms could also have obliterated much evidence of previous earthquake-induced cohort regeneration.

On well-drained terrace soils, the lack of wetter microsites combined with angiosperm competition probably limited successful conifer regeneration, despite the variation in conditions created by disturbances over the last 800 years. This does not support the predictions of the 'two-component system' model of angiosperm, conifer coexistence (Ogden \& Stewart 1995). In this model, large disturbances provide a release from angiosperm competition for shade-intolerant conifers in the regeneration phase. No distinction is made with respect to drainage in the model, so species should respond in a similar way to disturbances on differently drained soils. Lusk \& Smith (1998) suggest that chance and greater longevity are enough to sustain Dacrydium in $N$. menziesii/W. racemosa dominated forests on welldrained soils. In forests without Nothofagus, Dacrydium can regenerate on well-drained hill slopes following large disturbances (Ogden \& Stewart 1995), indicating their fundamental niche is broader than their restriction to saturated soils in our study. Conifers have the functional constraint of a less efficient vascular system inhibiting competitiveness (Bond 1989; Midgley \& Bond 1991). This is critical in the juvenile stage because conifers have low maximum rates of conductance or photosynthesis, meaning that they have slow early growth rates than angiosperms (Bond 1989; Midgley \& Bond 1991). Our results better support Bond's (1989) theory that conifers are out-competed by angiosperms where conditions were conducive for rapid growth, and that conifers are restricted to areas where angiosperm vigour is reduced. Hence, in our study underlying drainage is the major determinant of species composition. The different types of disturbances influenced relative species abundance, through the interactions of the resultant size of the canopy openings and the availability of differently drained microsites.
Acknowledgements. We are grateful to Ken and Robyn Ferguson for their hospitality. We thank Andrew Wells, Louise Cullen, Matthew Oliver, Fiona Carmichael, Gillian Dennis, Rhonda Pearce, Michael Urlich, Nicholas Urlich and John Fisher for field assistance. We acknowledge funding support from the Canterbury Botanical Society, Robert C. Bruce Trust, Ministry of Agriculture and Forestry, Lance McCaskill Memorial Scholarship, William Georgetti Scholarship, and the Lincoln University Doctoral Scholarship. We thank Jeremy Rolfe for figure preparation, and Chris Edkins for drafting the stem maps. Andrew Wells, Colin Miskelly, Susan Wiser and three anonymous referees provided comments that significantly improved this manuscript.

\section{References}

Almond, P.A. 1997. Soils and geomorphology of a lowland rimu forest managed for sustainable timber production. $\mathrm{PhD}$ Thesis, Lincoln University, Canterbury, NZ.

Belbin, L. 1989. PATN pattern analysis package. CSIRO, Canberra, AU.

Benn, J.L. 1990. A chronology of flooding on the West Coast 1846-1990. West Coast Regional Council, Greymouth, NZ.

Bond, W.J. 1989. The tortoise and the hare: ecology of angiosperm dominance and gymnosperm persistence. Biol. J. Linn. Soc. 36: 227-249.

Boose, E.R., Serrano, M.I. \& Foster, D.R. 2004. Landscape and regional impacts of hurricanes in Puerto Rico. Ecol. Monogr. 74: 335-352.

Crawley, M.J. 1997. Plant ecology. Blackwell Science, Oxford, UK.

Cullen, L.E., Stewart, G.H., Duncan, R.P. \& Palmer, J.G. 2001. Disturbance and climate warming influences on New Zealand Nothofagus tree-line population dynamics. J. Ecol. 89: 1061-1071.

Duncan, R.P. 1989. An evaluation of errors in tree age estimates based on increment cores in kahikatea (Dacrycarpus dacrydioides). N.Z. Natl. Sci. 16: 31-37.

Duncan, R.P. 1991. Competition and the coexistence of species in a mixed podocarp stand. J. Ecol. 79: 1073-1084.

Duncan, R.P. 1993. Flood disturbance and the coexistence of species in a lowland podocarp forest, south Westland, New Zealand. J. Ecol. 81: 403-416.

Duncan, R.P. \& Stewart, G.H. 1991. The temporal and spatial analysis of tree age distributions. Can. J. For. Res. 21: 1703-1710.

Foster, D.R. 1988a. Disturbance history, community organization and vegetation dynamics of the old-growth Pisgah forest, south-western New Hampshire, U.S.A. J. Ecol 76: 105-134.

Foster, D.R. 1988b. Species and stand response to catastrophic wind in central New England, U.S.A.J.Ecol.76: 135-151.

Foster, F.W. 1931. A stand of beech regeneration of known age. N.Z. J. For. 3: 39-40

Franklin,D.A. 1969. Growth rings in rimu from south Westland terrace forest. N.Z.J. Bot. 7: 59-70.

Grant, P.J. 1985. Major periods of erosion and alluvial sedimentation in New Zealand during the Late Holocene. 
J. R. Soc. N.Z. 15: 67-121.

Harmon, M.E., Bratton, S.P. \& White, P.S. 1983. Disturbance and vegetation response in relation to environmental gradients in the Great Smoky Mountains. Vegetatio 55: 129139.

Hosking, G.P. \& Kershaw, D.J. 1985. Red beech death in the Maruia Valley, South Island, New Zealand. N. Z. J. Bot. 23: 201-211.

June, S.R. 1982. Ecological studies in the indigenous forests of North Westland. Ph. D. Thesis, University of Canterbury, Christchurch, NZ.

Kitzberger, T., Veblen, T.T. \& Villalba, R. 1995. Tectonic influences on tree growth in northern Patagonia, Argentina: the roles of substrate stability and climatic variation. Can. J. For. Res. 25: 1684-1696.

Legendre, P. \& Fortin, M.J. 1989. Spatial pattern and ecological analysis. Vegetatio 80: 137-138.

Lusk, C.H. \& Smith, B. 1998. Life history differences and tree species coexistence in an old-growth New Zealand rainforest. Ecology 79: 795-806.

Midgley, J.J. \& Bond, W.J. 1991. Ecological aspects of the rise of angiosperms: a challenge to the reproductive superiority hypotheses. Biol. J. Linn. Soc. 44: 81-92.

Miller, T.E. 1982. Community diversity and interactions between the size and frequency of disturbance. Am. Nat. 120: 533-536.

Moorhouse, R. 1939. The growth of even-aged young Nothofagus forest in the more accessible and better quality sites of the Reefton District. N.Z. J. For. 4: 204-217.

Moran, P.A.P. 1950. Notes on the continuous stochastic phenomena. Biometrika 37: 17-23.

Norton, D.A. 1983. Modern New Zealand tree-ring chronologies 2. Nothofagus menziesii. Tree-Ring Bull. 43: 39-49.

Norton, D.A., Palmer, J.G. \& Ogden, J. 1987. Dendroecological studies in New Zealand: 1. An evaluation of tree age estimates based on increment cores. N.Z.J. Bot. 25: 373383.

Ogden, J. \& Stewart, G.H. 1995. Community dynamics of the New Zealand conifers. In: Enright, N.J. \& Hill, R.S. (eds.) Ecology of the Southern Conifers, pp. 81-119. Melbourne University Press, Melbourne, Australia.

Oliver, C.D. \& Stephens, E.P. 1977. Reconstruction of a mixed-species forest in central New England. Ecology 58: 562-574.

Pollmann, W. \& Veblen, T.T. 2004. Nothofagus regeneration dynamics in south-central Chile: a test of a general model. Ecol. Monogr. 74: 615-634.
Rogers, G. 1989. Beech and conifer community interactions in Moawhango ecological region, North Island, New Zealand. N. Z. J. Ecol. 12: 47-61.

Romme, W.H. \& Knight, D.H. 1981. Fire frequency and subalpine forest succession along a topographic gradient in Wyoming. Ecology 62: 319-326.

Smale, M.C., Van Oeveren, H., Gleason, C.D. \& Kimberley, M.O. 1987. Dynamics of even-aged Nothofagus truncata and N. fusca stands in north Westland, New Zealand.N.Z. J. For. Sci. 17: 12-28.

Spies, T.A. \& Franklin, J.F. 1989. Gap characteristics and vegetation response in coniferous forests of the Pacific Northwest. Ecology 70: 543-545.

Stewart, G.H., Rose, A.B. \& Veblen, T.T. 1991. Forest development in canopy gaps in old-growth beech (Nothofagus) forests, New Zealand. J. Veg. Sci. 2: 679-690.

Stewart, G.H., Basher, L.R., Burrows, L.E., Runkle, J.R., Hall, G.M.J. \& Jackson, R.J. 1993. Beech-hardwood forest composition, landforms, and soil relationships, north Westland, New Zealand. Vegetatio 106: 111-125.

Urlich, S.C. 2000. Coexistence, dynamics and disturbance history of a mixed conifer, beech, and hardwood forest, north Westland. Ph. D. Thesis, Lincoln University, NZ.

Veblen, T.T. \& Stewart, G.H. 1982. On the conifer regeneration gap in New Zealand: the dynamics of Libocedrus bidwillii stands on South Island. J. Ecol. 70: 413-436.

Veblen, T.T., Kitzberger, T.\& Lara, A. 1992. Disturbance and forest dynamics along a transect from Andean rain forest to Patagonian shrubland. J. Veg. Sci. 3: 507-520.

Vittoz, P., Stewart, G.H. \& Duncan, R.P. 2001. Earthquake impacts in old-growth Nothofagus forests. J. Veg. Sci. 12: 417-426.

Wardle, J.A. 1984. The New Zealand beeches: ecology, utilisation and management. New Zealand Forest Service. Wellington, NZ.

Wells, A., Stewart, G.H. \& Duncan, R.P. 1998. Evidence of widespread, synchronous, disturbance-initiated forest establishment in Westland, New Zealand. J.R. Soc. N.Z.28: 333-345.

Wells, A., Yetton, M.D., Duncan, R.P.\& Stewart, G.H. 1999. Prehistoric dates of the most recent Alpine Fault earthquakes, New Zealand. Geology 27: 995-998.

Wells, A., Duncan, R.P. \& Stewart, G.H. 2001. Forest dynamics in Westland, New Zealand: the importance of large, infrequent earthquake-induced disturbance. J. Ecol. 89: 1006-1018.

Whittaker, R.H. 1956. Vegetation of the Great Smoky Mountains. Ecol. Monogr. 26: 1-80.

Received 6 May 2004;

Accepted 20 June 2005.

Co-ordinating Editor: S. Wiser. 